\title{
SLOVENSKÝ PREKLAD GOETHEHO FAUSTA V RUKOPISNEJ POZOSTALOSTI KAROLA STRMEŇA
}

\author{
JÁN ČAKANEK
}

Filozofická fakulta Univerzity Konštantína Filozofa v Nitre

\begin{abstract}
Abstrakt: Zo slovenských prekladov Goetheho Fausta sa fragmentárny preklad Karola Strmeňa z konca štyridsiatych alebo začiatku pätdesiatych rokov 20. storočia ocitol úplne mimo akademického diskurzu. Dosial' ležal nepovšimnutý v Literárnom archíve Slovenskej národnej knižnice ako súčast’ autorovej rozsiahlej rukopisnej pozostalosti prenesenej z USA. Absencia jeho kritickej reflexie spôsobila ruptúru v kontinuálnom mapovaní faustovských prekladov na Slovensku a vytvorila ilúziu o neochvejnom postavení reprezentatívneho prekladu Mórica Mittelmanna Dedinského zo šesṫdesiatych rokov 20. storočia. Hlavným ciel'om tejto štúdie je približit osobnosṫ Karola Strmeňa cez prizmu extratextových faktorov (socio-historický kontext, subjekt prekladatel'a, politické gesto a politická udalost') a určit mieru ich vplyvu na Strmeňovu prekladatel'skú poetiku. Tú budem analyzovat metódou striktnej komparácie štruktúrnych a estetických dominánt prekladu s originálom Johanna Wolfganga Goetheho.
\end{abstract}

Klúčové slová: Karol Strmeň, Johann Wolfgang Goethe, Faust, preklad, exil

\section{Karol Strmeň ako prekladatel'ská osobnost'}

Karol Strmeň, občianskym menom Karol Bekényi (9. 4. 1921, Slovenský Meder, dnešné Palárikovo), je opomínaným géniom slovenskej prekladovej spisby. Literárni a prekladoví kritici si len pomaly začínajú uvedomovat jeho prínos pre slovenskú kultúru, i ked' vydobytý prevažne v exile.

Býva zarad’ovaný k predstavitelom slovenskej katolíckej moderny, akými boli Janko Silan, Mikuláš Šprinc, Gorazd Zvonický či Rudolf Dilong, no sám sa k nej nehlásil. ${ }^{1}$ Niežeby svoju konfesiu tajil, skôr sa chcel ešte striktnejšie vyhradit’ voči vtesnávaniu do jedného regionálneho alebo národného rámca. Ak katolicizmus, tak vel'kého formátu - univerzálny, integrujúci, prekračujúci hranice. Azda i preto v nehostinných podmienkach vel'kého sveta vydržal tak dlho. Motiváciami mu boli vyšší zmysel, skrytá spiritualita, pravda a očista, ktoré hl'adal v utrpení mimo vlasti - samo toto hl'adanie ho udržiavalo pri živote. Emigroval pred rýchlo postupujúcou Červenou armádou začiatkom roka 1945, najprv do Rakúska a Nemecka, potom do Talianska, až kým sa v roku 1947 na istý čas neusadil v Scrantone (Pensylvánia, USA), odkial' sa v roku 1952 definitívne prestahoval do Clevelandu (Ohio, USA). Slovensko navštívil v rokoch 1990, 1992 a 1993. Zomrel 15. 10. 1994 pri tragickej autonehode v lesoch za Clevelandom. Mal 73 rokov.

Modernistom bol tiež len sčasti; mal v sebe privel’a klasických hodnôt. Krédom mu bola ideovost', triezva myšlienka v jasnom tvare, nie avantgardná preestetizova-

\footnotetext{
${ }^{1}$ Cit. podl’a KRUŽLIAK, I. Živé stopy. Cambridge, Ontário : Dobrá kniha, 1975, s. 156.
} 
nost', najmä surrealistická, ktorá mnohé zatemňuje a v mnohom je samoúčelná. Ak sa riadil nejakým estetickým princípom, potom spočíval v katarznej zámlke nevypovedatel'ného a v začleňovaní čitatel’a do spoluutvárania zmyslu, ako to v úvode k tretiemu zväzku básnického diela Karola Strmeňa načrtáva literárny vedec Július Pašteka: „Čo básnik obsahovo utajuje, to si čitatel” má postupne odkrývat.."2 To mal spoločné s modernistami a symbolistami Ivanom Kraskom, Valentínom Beniakom, ale aj Milanom Rúfusom. Filozoficko-teologickým, avšak nie bigotným nazeraním do univerzálnych tém reflektoval číru objektivitu sveta, večné a nemenné esencie, idey v striktne platónskom zmysle slova. Nie živelný výlev krívd, ale trpezlivé preosievanie, vylupovanie a opätovné zasadzovanie obnažených životných prapodstát do znaku slova bolo jeho poetickým modus operandi. Poéziu nekalil subjektívnymi pocitmi - bez nostalgie a lacného sentimentu sa podla vlastných slov usiloval dostat' „k trvalej, neúprosne tvrdej a omračujúcej realite vecí ${ }^{\prime 3}$. To je jej najväčšia devíza. Hodno sa nazdávat', že práve táto črta Strmeňovej pôvodnej tvorby sa premietla aj do jeho prekladov, ktoré podl’a literárneho historika Petra Cabadaja patria „bezpochyby k tomu najkvalitnejšiemu, čo v dejinách slovenskej prekladovej literatúry vzniklo“"4.

Exil ako miesto doživotného vyhnanstva a neraz existenčnej núdze vplýval na prekladovú tvorbu Karola Strmeňa z istého hl'adiska aj pozitívne. Peter Cabadaj píše: „Americký exil ponúkol mimoriadne vnímavému a jazykovo kvalitne podkutému Karolovi Strmeňovi ideovo bezbrehý priestor a rozmer. Slobodný prúd rozmanitých myšlienkových tendencií, estetických programov, bezprostredný dotyk so svetovou literatúrou, moderným filozofickým a kultúrnym smerovaním, magický vplyv multietnického kultúrneho dedičstva - to všetko ho obklopovalo a Karol Strmeň plnými dúškami doslova hltal tento vábivý, neodolatel’ný a najmä inšpiratívny gejzír poznania. Konkrétne plody sa (...) najintenzívnejšie premietli do jeho monumentálnej prekladatel'skej činnosti (...). ${ }^{.5}$

Druhý aspekt tejto Strmeňovej „monumentálnej prekladatel’skej činnosti“ zhŕňa literárny vedec Matúš Marcinčin: „Písat či prekladat’ drámu bolo v situácii slovenských emigrantov v USA pragmaticky nezmyselné, ked’že nejestvovala možnost̉ jej profesionálnej divadelnej realizácie."6 Táto na prvý pohl’ad tienistá stránka prináša opät jedno nesporné pozitívum: oslobodzuje mysel’ od vonkajších popudov. Hoci v exile, Strmeň prekladal z intrinzitných, nie extrinzitných pohnútok. Neriadil sa pragmatickými motívmi, zákazkou alebo odporúčaním, ale vlastným hodnotovým cítením. Absencia komerčného tlaku a skrytej rivality, aká potahovala nitkami napríklad medzi Pavlom Országhom Hviezdoslavom a Martinom Braxatorisom-Sládkovičovom na domácej prekladatel'skej scéne ešte počas prvej svetovej vojny, viedla, hoc i v stažených podmienkach, k rozletu ducha a prekladu dodávala auru osobného zápalu.

Hlad po univerzálnych hodnotách sa prejavil primárne vo výbere prekladaných diel. Z drámy si Strmeň volí Eliotovu Vraždu v katedrále (Rím, 1979) či Claudelovu

${ }^{2}$ PAŠTEKA, J. Všetky cesty vedú domov. In STRMEŇ, K. Znamenie ryby. Bratislava : Petrus, 2001, s. 19.

${ }^{3}$ Cit podla CABADAJ, P. Literárny slovenský exil 1939 - 1990. Martin : Matica slovenská, 2002, s. 74.

${ }^{4}$ Tamže, s. 72.

${ }^{5}$ CABADAJ, P. Básnická tvorba Karola Strmeňa. In Biografické štúdie 28. (Ed. A. Matoočík). Martin : Slovenská národná knižnica, 2002, s. 109.

${ }^{6}$ MARCINČIN, M. Slovenský Shakespeare v americkom exile. In Slovenské divadlo, 2017, roč. 65, č. 1, s. 8. DOI: https://doi.org/http://doi.org/10.1515/sd-2017-0001. 
Saténovú črievicu (Bratislava, 2007); z lyriky sú to Poeov Havran (Ružomberok, 1944)7, Danteho Božská komédia (čast’ Peklo, Cleveland, Rím, Mníchov, 1965), taktiež výbery z Francesca Petrarcu (Vavrín, Rím, 1974) alebo z Tu Fua (Stokvetá rieka, Bratislava, 1998). Je to však len malá ukážka zo Strmeňovho ohromujúceho diapazónu. Dovedna mu vyšlo viac než 34 prekladových kníh (niektoré v reedíciách), no skutočne uchvacuje až jeho rukopisná pozostalost’ - obsahuje približne 7000 strán prekladov z viac než 23 autorov, medziiným fragmenty Shakespearovho Hamleta, Othella, Romea a Júlie, ale napríklad aj Schillerovej Márie Stuartovej. ${ }^{8}$

Hoci sa niektoré texty dosial' nepodarilo identifikovat', jeden z nich je nezamenitel'ný. V desiatej škatuli Strmeňovho osobného fondu v Literárnom archíve Slovenskej národnej knižnice sa nachádza fragment prekladu Goetheho Fausta, dovedna 52 strojopisných strán s rukopisnými korekciami a s poznámkou „neúplný“. Preložených je sedem scén: Prológ v nebi, Auerbachova pivnica v Lipsku, Susedin dom, Les a jaskyňa, Grétkina izba, Katedrála a Valpurgina noc ${ }^{9}$; Susedin dom má aj druhú, nedokončenú verziu.

Ak literárny vedec Miloš Tomčík hovorí, že Strmeňova prekladatel'ská fokusácia si popri inom vyžadovala „zmysel pre objektívne myšlienkové a estetické hodnoty a pre ich organické začleňovanie do tradícií slovenskej poézie ${ }^{\prime 10}$, potom je výber Goetheho Fausta vzhl'adom na slovensko-nemecké literárne vzt’ahy, zakorenené hlboko v baroku a kulminujúce u štúrovskej romantickej generácie, opodstatnený dvojnásobne. O to väčšia škoda, že na Strmeňove preklady z germanofónnych literatúr dosial' nikto nereflektoval a že sa mu za jeho preklady en bloc dosial' nedostalo náležitej oficiálnej pocty. ${ }^{11}$

O Strmeňovej všeobecnej prekladatel’skej svedomitosti svedčí spolupráca s kolegami filológmi v Clevelande (od roku 1966 bol profesorom románskych filológií a komparatívnej literatúry na tamojšej štátnej univerzite). Pri prekladaní z jazykov, v ktorých sa necítil byt úplne kompetentný, si neváhal vypomôct' francúzskymi

\footnotetext{
${ }^{7}$ Strmeň preložil Havrana štyrikrát. Z toho sa zachovali tri preklady. Ich porovnávacou analýzou sa zaoberá M. Marcinčin. Pozri MARCINČIN, M. Unikátne slovenské preklady Havrana E. A. Poa a ich vplyv na pôvodnú tvorbu Karola Strmeňa. In Trends in Slavic Studies. (Eds. E. F. Quero Gervilla - B, Barros García T. R. Kopylova). Moskva : URSS, 2015, s. 237 - 247. ISBN 978-5-396-00701-7.

${ }^{8}$ Pozri MARCINČIN, M. Krištál' na zabudnutom ostrove. (Dráma života Karola Strmeňa v súvislostiach). In Slováci v zahraničí, 35 : Zborník Krajanského múzea Matice slovenskej. (Ed. Z. Pavelcová). Martin : Matica slovenská, 2018, s. 37 - 40.

${ }^{9}$ Zredigovaný preklad Valpurginej noci pozri Fraktál, 2020, roč. 3, č. 4, s. $70-80$.

${ }^{10}$ TOMČ́́K, M. Kontúry prekladovej tvorby Karola Strmeňa. In Slavica Slovaca, 1991, roč. 26, č. 4, s. 269.

${ }^{11} \mathrm{~V}$ tejto súvislosti sú zvlášt pregnantné slová Mariny Čarnogurskej: „Napriek všetkému, čo Karol Strmeň svojím obrovským prekladatel'ským dielom pre slovenskú kultúru vykonal, je úplne nepochopitel’né a zahanbujúce, že sa dodnes nenašla na Slovensku intelektuálna vôla ocenit’ jeho osobnost' ,in memoriam' Cenou Jána Hollého za celoživotné prekladatel’ské dielo. A výhovorka, že Cena Jána Hollého pre cudzieho štátneho občana neexistuje, alebo že Karolovi Strmeňovi ju udelit nemožno práve preto, že bol cudzí štátny občan, je nesmierne prízemná.“ Pozri ČARNOGURSKÁ, M. V poézii - ide o život. In Kultúrny život, 2001, roč. 2, č. 49, s. 10, 5. 12. 2001. Július Pašteka v tom istom roku akoby spečatil opodstatnenost Čarnogurskej varovného tónu: „Ked’ mal [Karol Strmeň; pozn. J. Č.] konečne možnost' po desatročiach navštívit slobodné Slovensko, dokonca po tri razy - v rokoch 1990, 1992 a 1993 - presvedčil sa, že ani tu sa na neho nezabudlo. Hoci ,americký občan', neprichádzal ako cudzinec, prišiel ako rodák. Tak ho vítali a prijímali." Pozri PAŠTEKA, J. Všetky cesty vedú domov. In STRMEŇ, K. Znamenie ryby, s. 7. Najradikálnejší je však Matúš Marcinčin: „Dlhé roky pre slovenskú literatúru neexistoval. No slovenská literatúra ho potrebuje viac než on ju. [...] Slovenská literatúra potrebuje Strmeňove básne a preklady sama pre seba a kvôli sebe." Pozri MARCINČIN, M. Krištál' na zabudnutom ostrove. (Dráma života Karola Strmeňa v súvislostiach), s. 36.
} 
a anglickými prekladmi, vrátane sprievodných komentárov a poznámok. Preklady do antológie zo svetovej lyriky Návštevy (Rím 1972) ${ }^{12}$, medzi ktorými nechýbajú ani Goetheho básne Ganymedes, Pútnikova nočná pieseň a Pieseň sudičiek, dokonca posielal svojim ideovým súpútnikom na Slovensku Jankovi Silanovi a Mikulášovi Gacekovi „na akési odobrenie ich výrazovej autentickosti i bezprostredného zvukového a rytmického cvengu"13.

Táto antológia v skoncentrovanej podobe dokumentuje Strmeňovu fenomenálnu multilingválnost', ktorej obdobu by sme v slovenskom, európskom, ba svetovom

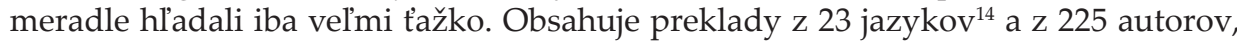
od starovekej poézie cez stredovekú a novovekú až po moderných básnikov prvej polovice 20. storočia. ${ }^{15} \mathrm{Na}$ prekladatel’a mal takýto široký záber recipročný vplyv. Na jednej strane ho rôznojazyčné kánonické texty nútili zušlachtovat vlastné prekladatel'ské umenie a udržiavat' v kondícii vlastný materinský jazyk, akokolvek geograficky vzdialený, na druhej strane sa v interpretačných a kreačných fázach dostával čoraz hlbšie pod lingvistickú krustu textu, až kým nenarazil na samotné fundamenty, uholné kamene príslušnej národnej kultúry.

Strmeň videl zmysel prekladatel’skej práce v tom, že mu dávala krídla, a súčasne ho zaväzovala k zodpovednosti. ${ }^{16}$ Prekladanie prirovnával k letu s odstrihnutými krídlami ${ }^{17}$ či k váženiu motýlích krídel ${ }^{18}$. Ústredným motívom krídel napokon uzatvára aj svoju úvahu o antinómii vernost' - vol'nost', resp. akademickost' - básnickost' umeleckého prekladu: „(...) [p]reklad má byt’ predovšetkým zrkadlom, nie - ako sa v teórii prekladu hovorí - kolonizáciou, extenziou prekladatel’ovej osobnosti. V praxi sa to prejavilo na viacerých rovinách. Nesmeli sme robit’ svojho Petrarcu, ale ani slúžit pôvodine až tak otrocky, aby sme ju v preklade deformovali pseudovernostou. To viedlo neraz k ostrým dilemám a bolestným rozhodnutiam, ktoré znamenali popretie našej vlastnej poetiky a istých ,záchranných' zvyklostí, ktoré sú u každého básnika väčšinou východiskom z núdze. (...) Preto v duele medzi linguistickou doslovnostou a eleganciou volili sme si vel’mi t’ažkú strednú cestu. (...) Prekladatel' vie, že nech by čo robil, nemôže nebyt’ du côté de son temps'. (...) [N]aším zámerom bolo spojit radostné štúdium s najširším možným rozpätím krídel (...). “19

Tento v jadre kreolizačný prístup sa Strmeňovi podarilo uplatnit nielen pri prekladaní Petrarcu. Svedčia o tom pozitívne hodnotenia plejády prekladových kritikov. Miloš Tomčík vyzdvihuje Strmeňovu prekladovú originalitu, ked’ si pri transformovaní eufonických kvalít kultového refrénu Poeovho Havrana „zvolil za tažiskové

\footnotetext{
${ }^{12} \mathrm{~V}$ reedícii vyšla antológia aj na Slovensku (Martin : Matica slovenská, 2008). Na rozdiel od rímskeho vydania sú v nej zohl’adnené aj pôvodné korektúry prekladatel’a.

${ }^{13}$ TOMČÍK, M. Kontúry prekladovej tvorby Karola Strmeňa. In Slavica Slovaca, 1991, roč. 26, č. 4, s. 274.

${ }^{14}$ Mad’arčina, nemčina, angličtina, francúzština, španielčina, taliančina, latinčina, polština, ruština, starogréčtina, rumunčina, klasická čínština, japončina, bengálčina, hebrejčina, portugalčina, chorvátčina, slovinčina, holandčina, dánčina, flámčina, nórčina a švédčina.

${ }^{15}$ Pozri ČARNOGURSKÁ, M. V poézii - ide o život, s. 10.

${ }^{16}$ Pozri ZAMBOROVÁ, M. Preložit báseň je ako obrátit dýku proti sebe. Rozhovor s Karolom Strmeňom. In Revue svetovej literatúry, 1992, roč. 28, č. 6, s. 73.

${ }^{17}$ Pozri CABADAJ, P. Literárny slovenský exil 1939 - 1990, s. 73.

${ }^{18}$ Pozri ČARNOGURSKÁ, M. Výnimočná hodnota Strmeňových básnických prekladov z klasickej čínštiny. In Biografické štúdie 28. (Ed. A. Matovčík). Martin : Slovenská národná knižnica, 2002, s. 129.

${ }^{19}$ Cit. podla MARCINČIN, M. Slovenský Shakespeare v americkom exile, s. 12.
} 
hlásky i, e - teda hlásky vysokého timbrového zafarbenia“20, a nie aj temnú hlásku o alebo sonóru r, ako je to v origináli a ako to pred ním urobil ovela rigoróznejší Vladimír Roy. Originalitu na vyššej úrovni si všíma aj Matúš Marcinčin, ked' dokazuje, že pri prekladaní Hamleta sa Strmeň „,vôbec neopieral o vtedajší nový český Saudkov preklad“21. Jozefovi Mihalkovičovi imponuje spôsob, akým Strmeň narába s rodným jazykom: pri čítaní prekladu Rilkeho Sonetov Orfeovi sa vraj čudoval jeho „rečovým manipuláciám ako nepredvídatel’ným letovým obratom roja škorcov“22. Ján Zambor víta najmä zvýšenú variabilitu cezúry a tonickú uvolnenost jambického metrického systému v Strmeňovom preklade Danteho Pekla, ktorú považuje za prostriedok približovania sa k originálu, resp. za „prvok vivifikácie rytmu“23.

Z obsahového hl'adiska Ladislav Franek oceňuje predovšetkým Strmeňov holistický prístup k textu: „Prekladatel’ správne pochopil, že podstata Claudelovej poézie spočíva v prirodzenom, jednotnom vyznení veršového celku, a nie v jednotlivostiach, ktoré boli neopodstatnene vyzdvihované najmä u Lukáča a Harantu “"24 Podl’a Júliusa Pašteku, Strmeň hodnoverne pretlmočil „híbkovú emocionalitu i formálne kvality Eminescových básní" 25 - Viliam Turčány dokonca tieto preklady hodnotí vyššie než Kraskove ${ }^{26}$. Marina Čarnogurská stavia na piedestál Strmeňovo trojrozmerné vizuálne vnímanie ideografických symbolov staročínskej poézie, vd’aka ktorému „,vytvoril v slovenčine taký hodnoverný preklad napríklad Tu Fuovho básnického diela, aký žiadna iná národná západná literatúra doteraz ešte nemá“ “27. Tento kongeniálny výkon nepochybne pramení aj zo Strmeňovho identifikovania sa "s týmto stredovekým čínskym vojnovým vyhnancom i spoločensky zneuznaným a fyzicky ubíjaným básnickým géniom“28. Literárna kritička Anami Amakijo akcentuje Strmeňovu bezprostrednost’ a intuíciu: Hoci nebol orientalistom, medzi jeho prekladmi starojaponskej poézie „[l]en výnimočne (...) nájdeme báseň, pri čítaní ktorej sme presvedčení, že mu unikla podstata, že sa nedostal pod povrch obrazu“. ${ }^{29}$

Menej pozitívne sa vyjadril romanista Anton Vantuch, ktorý Strmeňovi pri preklade Danteho Pekla vyčítal jednak neakademický prístup k pôvodine a z neho vyvierajúce obsahové nepresnosti, jednak oslabenú fonetickú inštrumentáciu verša. ${ }^{30}$ Translatologičku Dagmar Sabolovú najviac iritoval Strmeňov archaický jazyk, akoby

${ }^{20}$ TOMČÍK, M. Kontúry prekladovej tvorby Karola Strmeňa. In Slavica Slovaca, 1991, roč. 26, č. 4, s. 277.

${ }^{21}$ MARCINČIN, M. Slovenský Shakespeare v americkom exile, s. 18.

${ }_{22}^{2}$ MIHALKOVIČ, J. Ako nepredvídatelný letový obrat roja škorcov. In Revue svetovej literatúry, 1992, roč. 28 , č. 6, s. 77 .

${ }^{23}$ ZAMBOR, J. O troch slovenských prekladoch Danteho Pekla. In Romboid, 2008, roč. 43, č. 3, s. 33.

${ }^{24}$ FRANEK, L. Štýl prekladu : vývinovo-teoretická a kritická analýza slovenských prekladov Paula Claudela. Bratislava : Veda, 1997, s. 89.

${ }^{25}$ PAŠTEKA, J. Predstavil nám Eminesca. In EMINESCU, M. Ďaleko od teba. Bratislava : Petrus, 1999, s. 72.

${ }^{26}$ Tamže, s. 73.

${ }^{27}$ ČARNOGURSKÁ, M. Výnimočná hodnota Strmeňových básnických prekladov z klasickej čínštiny, s. 125 .

${ }^{28}$ ČARNOGURSKÁ, M. Strmeňov Tu Fu po dvadsiatich ôsmich rokoch. In TU, F. Stokvetá rieka (výber zo staročínskych originálov). Bratislava : Petrus, 1998, s. 220.

${ }^{29}$ AMAKIJO, A. Nad dvoma prekladmi starojaponskej poézie. In Knižná revue, 2005, roč. 6, č. 16 - 17, s. 7.

${ }^{30}$ Pozri VANTUCH, A. Ďalší slovenský preklad Danteho Pekla. In Slovenské pohl'ady, 1966, roč. 82, č. 7, s. 134. 
nebol schopný „intenzívnejšie siah[nut] do zdrojov vlastnej slovnej zásoby“31, a tiež, že konkrétne obrazy Danteho originálu „uvádzal na všeobecnú bázu v snahe dał im širší všel'udský význam“32.

Táto konštatácia nie je podložená dostatočne pádnymi argumentmi. Je doložená iba jedným nepresvedčivým príkladom bez detailnejšej analýzy, napr. bez zohl'adnenia fenoménu funkčnej ekvivalencie. Napriek tomu aj negatívnu kritiku Antona Vantucha a Dagmar Sabolovej možno vnímat’ konštruktívne. Vo svojom minoritnom zastúpení paradoxne zintenzívňuje pozitívne ohlasy a v konečnom dôsledku signuje ich dôvodnost'.

\section{Ortografická analýza a datovanie Strmeňovho prekladu Fausta ${ }^{33}$}

Pri datovaní a chronologizácii Strmeňových prekladov sa možno opierat’ o historické pramene. V jednom liste povzbudzuje Mikuláš Šprinc Karola Strmeňa takto: „A preto len dokonč svojich jedenást’ rozrobených diel, dokonč Pribinu a dokonč Danteho, dokonč Fausta, dokonč Strindberga, dokonč celého Shakespeara. Dokončme všetko, čo v srdci máme; i ked’ na všetkom bude bozk horký úzkosti, v ktorej nám treba žit', ktorú nám treba dýchat." ${ }^{34}$ List je datovaný do obdobia rokov 1951 - 1952, Strmeň teda musel mat’ v tomto čase preklad Fausta už rozpracovaný.

Ak sa túto tézu pokúsime podporit’ z hl'adiska vývinu kodifikovanej normy slovenčiny, t. j. detailnou analýzou ortografických tvarov rukopisu, ktoré sa od dnešnej spisovnej normy zjavne odchyl'ujú, potom budú pri určovaní približnej doby vzniku Strmeňovho prekladu aj vzhl'adom na Šprincov list najsmerodajnejšie Pravidlá slovenského pravopisu z roku $1953 .{ }^{35} \mathrm{~V}$ nich oproti pravidlám z tridsiatych a štyridsiatych rokov došlo k najzásadnejším zmenám. Najväčšou bolo zjednotenie písania l-ových particípií na tvar s mäkkým i (li), ktorý pri písaní minulého času a podmieňovacieho spôsobu slovies používame dodnes.

V Strmeňovom preklade Fausta však prevládajú tvary korešpondujúce s Pravidlami slovenského pravopisu z roku $1931^{36}$ : 1) skrepenely (hnáty), porozpadávaly sa (skaly); 2) zaodely sa (strigy); 3) poškrabaly sa (král'ovná, šlachta a dvorné panie). Nie sú doložené iba väzby s neživotnými a životnými neutrami a so životnými maskulínami

${ }^{31}$ SABOLOVÁ, D. Preklady Danteho Pekla na Slovensku a v exile. In Kotázkam teórie a dejín prekladu na Slovensku II. (Ed. K. Bednárová). Bratislava : Ústav svetovej literatúry SAV, 1994, s. 196.

${ }^{32}$ Tamže.

${ }^{33}$ Citácie z nemeckého originálu Fausta sú označené skratkou „,v." (,verš“) s príslušným číslom verša a pochádzajú z nasledovného vydania: GOETHE, J. W. Faust-Dichtungen, Bd. I. Texte. (Ed. U. Gaier). Stuttgart : Reclam, 1999.

${ }_{34}$ ŠPRINC, M. ...za lásku sa neplatí. Martin : Matica slovenská, 2002, s. 145.

${ }^{35}$ PECIAR, Š. a kol. Pravidlá slovenského pravopisu s pravopisným a gramatickým slovníkom. Bratislava : SAV, 1953.

${ }^{36}$ VÁŽNY, V. Pravidlá slovenského pravopisu s abecedným pravopisným slovníkom. Praha : Štátne nakladatel'stvo, 1931. Podl'a týchto pravidiel sa l-ové particípium písalo s ypsilonom, ak sa viazalo 1) na neživotné substantívum akéhokolvek rodu (stromy kvitly, palice sa lámaly, mestá rástly); 2) na životné substantívum ženského alebo stredného rodu (ženy sa smialy, deti sa kúpaly); 3) na viacnásobný podmet, v ktorom nefiguroval mužský rod (ženy a deti sa zabávaly) alebo 4) na životné substantívum deklinované podla vzoru „dub“ (vtáky spievaly). Naopak, 1-ové particípium s mäkkým i sa písalo iba v spojení 5) s mužskými životnými substantívami skloňovanými podl’a vzoru "chlap“ (chlapci sa hrali, vtáci spievali) a 6) s viacnásobným podmetom, ktorý zahŕňal aj mužský rod (otcovia, ženy a deti sa zabávali; vtáci a ryby vyhynuli). Pozri s. $70-71$. 
deklinovanými podla vzoru dub. L-ové particípiá, ktoré sa v preklade vyskytujú, však i tak indikujú, že Strmeň sa riadil ešte starou pravopisnou normou. Pomýlit nás nesmú ani tvary spisovné po roku 1953, použité napr. v slovných spojeniach „všelikde sme chodili“" (Mefistofeles a Faust), „,dávno by ti už boli odzvonili“" (všeobecne), „aby sme aspoň spoločný hrob mali“ (Faust a Margaréta) - boli totiž spisovné už pred rokom 1953.

Nemožno teda uzatvárat', že ortografické javy prináležiace reforme spred roka 1953 „svedčia najskôr o nepozornosti prekladatela pri používaní novoosvojených pravopisných pravidiel“, ako to konštatuje Matúš Marcinčin ${ }^{37}$. Takýto záver môže platit pri iných Strmeňových prekladoch, pri preklade Fausta by však pramenil z neadekvátne zvolenej štatistickej metódy, ked’ sa vedl’a seba kladú staré a nové pravopisné tvary bez zohladnenia historickej podmienenosti. Nepomerný výsledok ${ }^{38}$ by potom mohol zviest’ k presvedčeniu, že staré tvary dokazujú iba neschopnost’ prekladatela prekonat’ zvyk, pretože nová kodifikácia bola v platnosti len vel'mi krátko. Ak zvážime, že tvary s -li boli gramaticky správne aj podl'a starého pravopisu, potom u Strmeňa pôjde, naopak, skôr o snahu dôsledne dodržat’ práve platnú normu.

Príkladom toho je replika postavy ministra v scéne Valpurgina noc, ked' Strmeň píše to isté sloveso raz s mäkkým i, raz s ypsilonom: „Ked’ ešte my sme boli pánmi kasy, / to boly časy, pravé zlaté časy“. Tvar „boli“ sa vzt’ahuje na generála, ministra, parvenu a spisovatel’a ako životné maskulína, tvar „boly“ na neživotnú fyzikálnu veličinu. Táto diferenciácia teda zodpovedá pravopisným pravidlám z roku 1931, resp. 1939 a 1940.

Dištinktívnu funkciu l-ového príčastia si Strmeň neuvedomuje azda len v jednom prípade. Ked' počas orgiastického výstupu na Brocken zhora jedna z bosoriek zavolá, aby sa pridali aj tie zdola, čo práve perú bielizeň v jazere, ozve sa odtial:" „Do výšky radi dostali by sme sa. / Perieme sa a bielime a zažívame obrodu, / ale sme i večne bez plodu." Z originálu nie je jasné, či sa pri jazere nachádzajú bosorky aj bosoráci, výklad predmetných veršov v Goetheho slovníku však napovedá, že iba bosorky. ${ }^{39}$ Prihliadnuc na dobový pravopis by teda veta mala zniet takto: „Do výšky rady dostaly by sme sa." Na druhej strane Strmeň správne dešifroval význam klúčového homonymného slova „blank“. Strigy sa naozaj iba skveli čistotou (prvý význam), a neboli nahé (druhý význam). Až teraz, po priamej apelácii, sa rozhodli vyzliect’ a pridat’ sa k obscénnym praktikám nahých čarodejníc - vystavit” sa „skoku“ muža ako animálnemu aktu plodenia. ${ }^{40}$

Druhým diskutabilným miestom z hl'adiska ortografie l-ových particípií je replika proktofantazmistu ${ }^{41}$, ktorý v rámci osvietenského mravokárstva karhá Fausta tancujúceho s nahou bosorkou: „Čertove deti! Predpisov sa zriekli.“ Dochádza tu ku konta-

${ }^{37}$ MARCINČIN, M. Slovenský Shakespeare v americkom exile, s. 9.

${ }^{38}$ V Strmeňovom preklade Fausta je počet slovesných tvarov zakončených na -ly 14 (rozosmialy, neboly (2x), žraly, poškrabaly, maly (2x), vznikly, porozpadávaly, skrepenely, zaodely, boly, skákaly, dráždily); počet slovesných tvarov zakončených na -li je 29 (urazili, prikvitli (autokorekcia pôvodného ekvivalentu), zabavili, predbehli, hovorili, vykrstili, dali $(2 x)$, poctili, nemali, vykropili, nešli, chodili, boli $(2 x)$, boli by odzvonili, mali (3x), porobili, dosiahli, prišli (2x), dostali, robievali, nevedeli, chceli, zriekli, nepočarili).

${ }^{39}$ Pozri Goethe-Wörterbuch, digitalisierte Fassung im Wörterbuchnetz des Trier Center for Digital Humanities, Version 01/21. [online]. [cit. 04. 04. 2021]. Dostupné na internete: http://woerterbuchnetz.de/cgi-bin/ WBNetz/wbgui_py?sigle=GWB\&mode=Vernetzung\&lemid=JB03331\#XJB03331.

${ }^{40}$ Pozri SCHÖNE, A. Johann Wolfgang Goethe, Faust. Kommentare. Frankfurt - Leipzig : Insel, 2003, s. 350.

${ }^{41}$ Nepreložitelný pojem. Narážka na historickú postavu Friedricha Nicolaia. Tamže, s. 358. 
minácii gramatickej a sémantickej roviny. Gramaticky by za substantívom „deti“ mal podl’a vtedajšieho úzu nasledovat tvar "zriekly“, sémanticky tvar "zriekli“. Strmeň zvolil jotu, uprednostňujúc všeobecný význam výpovede: Proktofantazmista pranieruje mystično, poverčivost', uvol'nenost' mravov a bezuzdnost' fantázie in genere; „čertove deti“ („Teufelspack“) je len prívlastok.

Ako snahu o gramatickú čistotu podla pravidiel z tridsiatych rokov 20. storočia možno v Strmeňovom rukopise klasifikovat’ aj iné tvary ako participiálne koncovky -li/-ly. Ide predovšetkým o etymologicky odôvodnené písanie menných a slovesných predpôn s- a z- v týchto zloženinách: svodnejšej, sbor, zkade (resp. zkadeže), zpráva, sniest', v smysle, sbohom, smyselnost', zpola, svalí, svezie, nesrazilo, zpod, shromažd’uje, slet, shora, sberba, smluva, zt’ato (nárečový výraz za stadial'to), sväzok $^{42}$ a o predložky s a so, viažuce sa s genitívom: s nebies, s klenby, s Brockenu, so všetkých strán.

Menej frapantné, najmä diakritické odchýlky v Strmeňovom texte sa už nedajú vysvetlił’ celkom jednoznačne. Nesprávna kvantita v slovách zahálky, zbrídil (resp. brídi), v brúšku, napúchnutej (resp. púchnu), listím (resp. listiu), do úška, rinku, najdem, zizajúca, žĺtne, strídži (resp. strídžej), na úzde ${ }^{43}$ a absencia vyznačovania či nadužívanie mäkkého l' v slovách zahálky, hobla, flaši, sysel, lapiet', šlahá, ul'ahodí a ofrflat' sú vo všetkých prípadoch javy odchylné aj od normy platnej pred rokom 1953. ${ }^{44}$ Môžu odrážat’ stratu kontaktu so slovenským jazykovým prostredím, t. j. skutočnost', že Strmeň nemal pravopisnú a zvukovú normu slovenčiny dobre vžitú, ale môžu súvisiet’ aj s nárečovým pozadím prekladatel'a. ${ }^{45} \mathrm{Na}$ niektorú z týchto alternatív poukazujú aj anomálie morfologického charakteru ako šnôrovačku (už podl’a vtedajších pravidiel malo byt’ šnúrovačku), odtedy, vozvyšok (malo byt’ vozvysok), nechet, koš, prt a bzúka.

Vzhl'adom na Strmeňovu jazykovú brilantnost’ je však pravdepodobnejšie, že všetky tieto pravopisné lapsusy pramenia z extrémne sústredenej cizelácie a harmonizácie významovej a štylistickej roviny textu. Príkladom môže byt’ výraz "lapiet" v Mefistofelovej výčitke Faustovi, ktorý si odišiel utriedit myšlienky do hôr: „Načo máš v tejto skalnej diere / lapiet jak sova zizajúca v šere?" Výraz lapiet’ sa v tejto konkrétnej podobe nenachádza v nijakom súčasnom ani dávnejšom slovníku. ${ }^{46} \mathrm{Vo}_{0}$ vel'kom Slovníku slovenského jazyka, II, L - O však nachádzame podobu „loptiet” s významom „vysedávat', trčat" ${ }^{\prime 47}$ a v Slovníku slovenských nárečí, II, $L$ - P ešte príbuznejšiu

\footnotetext{
${ }^{42}$ Pozri VÁŽNY, V. Pravidlá slovenského pravopisu s abecedným pravopisným slovníkom, s. 39.

${ }^{43}$ Slovo „prolog“" sa podl’a normy spred roka 1953 písalo s krátkym o. Názov scény Prolog v nebi je teda ortograficky korektný.

${ }_{44}^{4}$ Vzhl'adom na to, že Strmeňov preklad Fausta sa zachoval v strojopisnej podobe, by mohla absencia mäkkého l' poukazovat’ aj na skutočnost', že v čase, ked' už pôsobil v zahraničí, nemal vždy k dispozícii písací stroj so slovenskou, príp. českou klávesnicou. Ked’že je však výskyt slov bez mäkkého l’ nekontinuálny (v prvých dvoch scénach a v poslednej scéne), je to málo pravdepodobné. Navyše mäkké l’ absentuje aj v blízkosti slova s vokáňom (šnôrovačku), ktorý písací stroj s nemeckou ani českou klávesnicou nepozná. Dá sa teda predpokladat, že Strmeň síce Goetheho Fausta prekladal v zahraničí, avšak na slovenskom písacom stroji.

${ }^{45}$ Nie je bez zaujímavosti, že absenciu mäkkého l', resp. jeho nenáležité používanie nájdeme aj u iných prekladatel'ov, napr. u Blahoslava Hečka v preklade Rollandovho románu Dobrý človek ešte žije.

${ }^{46}$ Nenachádza sa v Czambelovej Rukoväti spisovnej reči slovenskej (1902) ani v smerodajnom Slovenskom frazeologickom slovníku Petra Tvrdého (1933), ale ani v príručke Pravidlá slovenského pravopisu s pravopisným slovníkom (1940) či v Pravidlách slovenského pravopis z roku 1953.

${ }^{47}$ PECIAR, Š. a kol. Slovník slovenského jazyka. II. L - O. Bratislava : SAV, 1960, s. 58.
} 
podobu „l'apiet", resp. rovnocenný tvar „l’aptiet“", t. j. výlučne s mäkkým l’ vo význame "nečinne sediet" "48. Naostatok sa výraz "l'apiet"“ nachádza aj v Synonymickom slovníku slovenčiny ako synonymum výrazu „sediet”“ a má štylistický kvalifikátor „expr., trocha hrub. “49. Strmeň mal nepochybne na mysli tento význam, len opät vynechal mäkčeň. Podstatné však je, že týmto expresívnym a trocha hrubým nárečovým výrazom funkčne vykompenzoval nemecký nárečový výraz „Schuhu“ (sova): „Was hast du da in Höhlen, Felsenritzen / Dich wie ein Schuhu zu versitzen?“ (v. 3272 a nasl.). Tým sa mu podarilo udržat’ dikciu repliky, hovorovým výrazom "pánbičkovi“ potom iba podčiarkuje Mefistofelov ironický tón.

Príslovkové tvary nedočkave, kysle a bláznive boli v štyridsiatych rokoch plne akceptovanými alternatívami k tvarom zakončeným na -o; podobne tak sa ani defektná deklinácia „v Padui“, „v Neapoli“ a „do hrudi“ nemusela pocitovat’ ako (napr. nárečovo) príznaková. Všetky tieto tvary boli alebo spisovné, alebo odrážali rozkolísanost’ dobovej spisovnej normy. Výraz „obrážtok“ si Strmeň zvolil v súlade s Goetheho poetikou ako expresívnejší ekvivalent k slovu obrážtek či obrázok, ktoré by sa takisto rýmovalo (na slovo „rok“); nádych archaickosti v tom čase ešte neniesol. Podobne neniesol nádych exotickosti či nespisovnosti bohemizmus "nezbýva“. 50 Tvary „výre“ (miesto výry), "lodi“ (miesto lode) a „vrchola“ (miesto vrcholu) možno zas hodnotit” ako akceptované neologizmy v službách rýmu, ked’že sa nachádzajú na konci veršov. Podobne tvar „francúha“ (miesto francúza) vo význame francúzskeho bozku („,z l’úbosti dostal francúha“) je najskôr produktom poetickej hry so zvukom (za účelom vytvorit’ rým na „mladucha“). Gramatické chyby vo veršoch „aby bol zverom viacej ako zveri“ (miesto zvery) a "tu sa mi ticho usadíme" (miesto my) sú najvážnejšími pravopisnými prehreškami; na druhej strane však môžu byt' - podobne ako preklepy v slovách "treaz" (miesto teraz), "Schwedtleinová" (miesto Schwerdtleinová) a "bachanálie" (miesto bakchanálie) - aj dôsledkom nepozornosti, resp. extrémnej koncentrácie na významovú zložku prekladu.

\section{Poetika Strmeňovo prekladu Fausta}

Pri kritickom čítaní Strmeňovho prekladu Fausta vystúpia okrem pravopisných odchýlok do popredia štýlové dominanty na úrovni verzologického, poetického, sémantického a intratextového ekvivalentu.

Aliteráciou v dvojverší „A na útesy more valí / záplavu zapenených vôd“51 Strmeň umocňuje slávnostný tón chválospevu archanjela Gabriela na vel'kolepé Božie diela. Zároveň táto zvukomalebná inštrumentácia vybočuje z inak dôsledne dodržiavaného hojdavého jambického rytmu stance, ktorú si Goethe rezervoval na zvlášt' hymnické, apoteózne pasáže. V preklade Strmeň navodzuje pulz morských príbojov, zmena rytmiky má významotvornú funkciu. Ďalšie vybočenie z pravidelného jambického rytmu cítit’ v kardinálnom výroku Pána: „Človek sa mýli, iba zakial’ zápolí.“ Hoci je

${ }^{48}$ BORČIN, E. a kol. Slovník slovenských nárečí. II. L - P. Bratislava : Veda, 2005, s. 29.

${ }^{49}$ PISÁRČIKOVÁ, M. a kol. Synonymický slovník slovenčiny. Bratislava : Veda, 2004, s. 634.

${ }^{50}$ Výraz je skôr rezíduom ideológie čechoslovakizmu za prvej Československej republiky, dokladom o zbližovaní češtiny a slovenčiny do jedného československého jazyka v dvoch variantoch (preferoval sa etymologický princíp na úkor fonologického). Pravdaže, Strmeň si pri prekladaní toto politicko-sociologické pozadie neuvedomoval.

${ }^{51}$ Pre lepšiu názornost’ graficky zvýraznil autor štúdie. 
táto daktylotrochejská rytmická licencia v preklade vzhl’adom na prízvučné pomery slovenčiny pochopitelná a všeobecne prijatá, Strmeň ju uplatňuje nie z nedostatku rytmickej vynachádzavosti, ale zámerne. Prízvučnými slabikami, ktoré navyše opät' ozvláštňuje aliteráciou, chce podčiarknut’ váhu pasáže pre celý nasledujúci dej. Zlad'ovaním rytmu a zvuku vyzdvihuje Faustov voluntarizmus, ktorý sa stane klúčovým faktorom v stávke o jeho dušu. V tomto ohlade je mimoriadne precízne zvolený aj knižný výraz „zápolit”“ za nemecké „streben“, totiž v dvojakom význame: 1. bojovat', zápasit’ a 2. pretekat', sútažit'. Všetky štyri sémantické odtienky neskôr vyústia do Faustovho megalomanstva, karierizmu, donchuanstva a imperializmu; Strmeň ich s nevídanou intuíciou anticipuje.

S rýmami pracuje rovnako profesionálne. Čisté rýmy (driečna - slečna, s vami - jamy, šklabí - štáby), ktoré ničím nevyrušujú, a tak sú praktickou ukážkou Strmeňovho postulátu, že „na mieste sú len tam, kde neznejú umelo, ale celkom prirodzene (...), ako keby tam ani neboli“52, strieda rýmami menej presnými, asonančnými (rozosmialy ${ }^{53}$ - si sto razy, hobla ${ }^{54}$ - dobrá, pod’akuj - na krku ${ }^{55}$ ), ktoré čitatel'a prebúdzajú, udržiavajú v ostražitosti, čím na druhej strane učiňuje zadost̉ Goetheho inklinácii k technicky nepresným rýmom: „Keby som bol ešte mladý a mal dost’ odvahy, úmyselne by som sa prehrešoval proti všetkým takým technickým vrtochom, používal by som aliterácie, asonancie a nesprávne rýmy, všetko, ako by som si zmyslel a bolo mi pohodlné; no dal by som sa na to hlavné a usiloval sa povedat také dobré veci, že by každého lákalo prečítat’ si to a naučit’ sa to naspamät." ${ }^{56}$ Nepresnými inovatívnymi rýmami, ktoré sa hojne vyskytujú aj v prvej časti Fausta (neu - sei, genug - Besuch, Floh - Sohn), Strmeň napĺña Goetheho zámer vylúpnut̉ jadro veci - ostávajú ohniskami výpovede. ${ }^{57}$

Pritom nepoužíva inverzie, aby rým dostal na koniec verša. V snahe o nevyumelkovanost', teda o prirodzený tok reči, iba ojedinele reorganizuje rýmovú schému. Napríklad v Prológu v nebi robí zo združeného rýmu prerývaný (pričom prvá konštanta nie je osihotená, viaže ju na predchádzajúcu pasáž) a hned’ nato zo striedavého obkročný. Miesto originálneho rýmového retazca befangen [a] - Wangen [a] - Haus $[b]$ - Maus [b] - überlassen [c] - ab [d] - erfassen [c] - herab [d] nás teda v preklade sprevádzajú rýmy neboly [a; viaže sa na predošlé rýmy] - plyš [b] - kríž [b] - myš [b] - vôlu [c] - žriedla [d] - vedlla [d] - dolu [c].

V rámci Goetheho vehementnej preferencie myšlienkovej čistoty na úkor formálnej však aj tento postup možno považovat’ za legitímny - podobne ako vnútorný rým na posilnenie akustickej zložky Froschovej piesne v Auerbachovej pivnici v Lipsku: „Otvor dvere! Hviezda kmitá. / Otvor, nespi, milá Zita. / Zavri! Svitá, už je deň.“ Táto pasáž je zároveň excelentným príkladom naturalizácie, ktorou Strmeň približuje Froschovu pieseň slovenskému l’udovému prostrediu, folklorizuje ju (v origináli sa

${ }^{52}$ Podla ČARNOGURSKÁ, M. Výnimočná hodnota Strmeňových básnických prekladov z klasickej čínštiny, s. 129.

${ }^{5}$ Správne má byt” "rozosmiali“.

${ }^{54}$ Správne má byt' "hobl'a".

${ }_{55}^{5}$ Strmeňova autokorektúra rýmu ",a posti - na starosti“

${ }^{56}$ Podla ECKERMANN, J., P. Rozhovory s Goethem v posledných rokoch jeho života. Bratislava : Slovenské vydavatel'stvo krásnej literatúry, 1960, s. 489.

${ }^{57}$ Zároveň sa v týchto rýmoch odrážajú interferencie medzi hesenským a durínskym nárečím. Ak teda Strmeň používa aj nárečové slová, príp. ich substituuje hovorovými (kobza, rínok, výre), je to adekvátny jav. 
milá menom neoslovuje). Za komplementárnu naturalizáciu možno považovat’ Mefistofelov ironický prehovor na Faustovu adresu ohl'adom Margaréty: „Kubo, ked” nevie, ako z konopí, / fantazíruje o smrti a tára.“ V origináli sa podobná nadávka (vo význame „trul'o") nenachádza; Goetheho výraz Köpfchen (hlavička) smeruje skôr k frazéme „lámat’ si hlavu“. Aj tento podtón však Strmeň vystihol s bravúrou, ked” sa chopil takmer zabudnutého slovenského porekadla "nevediet, kam z konopí", hoci ho kvôli rytmu modifikoval. ${ }^{58}$ Naostatok Strmeň naturalizuje aj formou nomen omen, a to znova ústami Froscha, ktorý sa z pozície vodcu bujarej družiny Mefistofela pýta: „Večeral s vami Jano Potrhlý?“ Takto Frosch reaguje na Mefistofelovu provokačnú poznámku, že páni pijú iba „,žbrndu“ - dáva mu najavo jeho drzost', nebodaj duševnú vyšinutost'. V origináli sa nachádza oslovenie „Herr Hans“ („pán Hans“) ako alúzia na Hansa Arsa, hostinského v Rippachu ned’aleko Lipska. Kvôli priezvisku Ars (v lipskom nárečí vyslovovanému ako Arsch [ав $]$ - Rit') sa stal terčom oplzlých žartov v širokom okolí už za Goetheho študentských čias.

Tendenciu zvyšovat' komunikatívnost' alebo, povedané slovníkom Františka Mika, zážitkovost’ a operatívnost̉ dialogických pasáží, badat' u Strmeňa na celej ploche textu. Eklatantným príkladom sú frazémy "mat' očko", "trúsit chvály", "nemat”

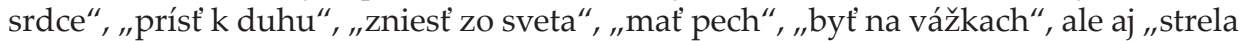
vašej materi", "námaha malá - vel'ký špás“, ba dokonca "Mňa v peňaženke diera páli“ - aktualizácia frazémy „Peniaze ho pália vo vrecku.“ Všetky tieto príznakové štylistické prostriedky Strmeň používa primerane komunikačnej situácii, darí sa mu nimi udržiavat’ vysokú mieru kolokability a autenticity výpovedí. Dosahuje ju aj okrídlenou frázou „Takú mu vrazím, že ho krv zaleje!“ a kusými eliptickými zvolaniami „Kdeže by on a dukáty!“ alebo „Medzi ne sa, synku!“

Jemnocitne Strmeň pracuje aj s expresivitou a zafarbením lexikálnych jednotiek. Na jednej strane sú to domáce (archaické, knižné či poetické) slová palota, zápač, pablesky, na druhej strane prevzaté, exoticky pôsobiace výrazy inkantácia, execírovat', separatista. Goethe varíruje básnické výrazivo podobne. Preklad navyše zdobia aj opakovacie štylistické figúry ako epizeuxa či epanadiplóza. Ked’ Strmeň necháva Mefistofela spievat: „Ušil jej oblek mäkušký, / natiahol na ňu plyš, / na háby stužky na stužky / a na hrdielko kríž", tak epizeuxou "stužky na stužky“ zosilňuje výraz „Bänder“ (stužky [radové, tu pri vymenúvaní za ministra na král’ovskom dvore pozn. J. Č.]; v. 2225); ked' necháva Mefistofela referovat Marte o posledných slovách jej zosnulého muža: „Ja sveta, vravel, neužíval som, / detváky, potom chleba pre detváky“, tak duplikáciou írečitého výrazu "detváky“ v rámci epanadiplózy, i ked” atypickej, zintenzívňuje životný pocit muža, ktorý pre blaho rodiny všetko obetoval. V origináli sa táto štylistická figúra nenachádza.

Strmeň sa skvie aj v rovine významu. V prológu sa Pán vyjadruje o Faustovi takto: „Trápi sa jeho mysel’ pomýlená, / privediem ho však čoskoro i na jasnejší schod.“ Jasnejší schod je explikáciou výrazu „Klarheit“ (jas; v. 309), ktorý sa dá interpretovat’ ako protiklad k temnému, kalnému a skreslenému pohl'adu tu na zemi, ale tiež

${ }^{58}$ Porov. SMIEŠKOVÁ, E. Malý frazeologický slovník. Bratislava : Slovenské pedagogické nakladatel'stvo, 1989 , s. 99. Ako o špecifickom type frazémy píše o porekadle „Nevediet,', kam z konopi“ ešte napríklad Jozef Mlacek. Pozri MLACEK, J. Osobitosti uplatňovania záporu vo frazeológii. In Slovenská reč, 2006, roč. 71, č. 2, s. 73 . 
v intenciách pravého, plne názorného transcendentálneho poznania sveta. ${ }^{59}$ Pridaním obrazného pomenovania „schod“ Strmeň navodzuje aj význam monády ako základnej duchovnej jednotky bytia, ktorá sa v človeku neustále zdokonaluje - akoby na ceste od kolísky po hrob kráčal po imaginárnych schodoch vyššie a vyššie k pravému svetlu poznania. Takto Strmeň do prekladu kóduje aj Goetheho životnú filozofiu nevyhnutnosti permanentného zdokonal'ovania sa. Ked' krátko nato prekladá: „A hanbi sa, až priznáš mi tu napokon, / že dobrý vidí, čo je správna méta, / i na úpadku hlbokom.", obohacuje túto filozofiu ešte o teleologický aspekt vynárania sa nových a nových ciel'ov, ktorých dosiahnutie, pokial' sú pozemské, človeka neuspokojí. Ohniskom tohto spinozistického svetonázoru je vkusný knižný výraz „méta“ na konci verša. V origináli Pán hovorí o pravej ceste („de[r] rechte[...] Weg[...]“; v. 329), čiže o niečom, čo k ciel'u iba vedie. Avšak aj cesta môže byt' ciel'.

Akiste len vd’aka svojej teologickej intuícii a silnému osobnému vzṫahu k transcendentnu Strmeň s úctyhodnou variabilitou pracuje aj so symbolikou svetla a tmy, ktorá je pre celú drámu Faust fundamentálna. Pán vo svojom záverečnom prehovore nazýva Mefistofela „potmehúdom“. Tento výraz je geniálny vzhl’adom na scénu Študovňa I, kde sa Mefistofeles charakterizuje ako čast' tmy, z ktorej sa zrodilo svetlo („Ein Teil der Finsternis, die sich das Licht gebar“; v. 1350). Strmeň svojím ekvivalentom charakterizuje Mefistofela ako toho, ktorý prináša tmu, ktorý človeku niečo „po tme hudie“, nahovára ho na zlé, hoci pôvodne mohol byt’ nositel’om svetla (Lucifer). Zároveň sa však Strmeňovi darí zachovat’ sémantický náboj originálneho výrazu „Schalk" - šibal, prefíkanec.

V takomto symbolistickom exponovaní svetla a tmy Strmeň pokračuje aj d’alej. V scéne Les a jaskyňa Mefistofeles prirovnáva Fausta k sove zízajúcej „v šere“. Takto Strmeň Faustovi vytyčuje miesto medzi svetlom a tmou, Bohom a diablom, dobrom a zlom. V súvislosti s Goetheho fenomenológiou farieb, ktoré chápal ako výsledok miešania svetla a tmy, je Faust vskutku zhumanizovanou pestrou zmesou týchto dvoch transcendentných entít - totálnej belosti a totálnej černe. Goethe na tomto mieste symboliku svetla a tmy neexponuje, zato je však bohato zastúpená inde, napr. v scéne Za bránou (v. 905 a nasl.), ktorá v Strmeňovom výbere chýba, alebo už v Predohre na javisku, kde „Veselá osoba“ („Lustige Person“), ktorá sa zvykne interpretovat ako Mefistofeles, hovorí o pestrých obrazoch s minimom jasu („In bunten Bildern wenig Klarheit“; v. 170) - človek je len potemneným obrazom vyššej reality. Toto temno Strmeň sprítomňuje viacnásobne: Faust sa skrýva v "tmavej rokli“ a posiela Mefistofela do „najtmavšej tône“, pretože mu pripomenul Grétku, ako opustená „spieva do tmy“. V origináli spieva dlho do noci („,halbe Nächte lang“, v. 3319) - v ostatných dvoch prípadoch nie je motív tmy prítomný ani latentne. Strmeňov variant „do tmy“ možno interpretovat' bud' vo význame do zotmenia, alebo vo význame, že jej spev plynie do temnoty a zaniká v nej. Týmto druhým významom Strmeň podčiarkuje Grétkinu zlovestnú predtuchu (bude st’atá).

Podobným spôsobom Strmeň vytvára siet’ sémantických vzt’ahov aj pri iných motívoch. Fenomenálnu intratextovú väzbu nachádzame v scéne Valpurgina noc, kde Mefistofeles počas zúrivého letu na Brocken za nočnými orgiami s vodcom satanov a húfom bosoriek a bosorákov opisuje, ako sa „lámu“ "stlípy večne zeleného chrá-

\footnotetext{
${ }^{59}$ Pozri GAIER, U. Johann Wolfgang Goethe, Faust-Dichtungen, 2. Kommentar I. Stuttgart : Reclam, 1999, s. 64 .
} 
mu“. Lámu sa stromy v lese, ktorý až dosial' býval „zeleným chrámom“, pevne ukotveným na živom prírodnom stĺpoví. Krátko nato už Mefistofeles hovorí o „dochrámanom rumovišti“. Strmeň aj touto sugestívnou zvukomal'bou predstavuje les ako dochrámaný chrám - sprznené rumovisko, ktoré ešte pred chvílou bolo svätyňou. Tento sémantický komplex sa naostatok prehlbuje aj d’alšou intratextovou väzbou: Mefistofeles síce opisuje „víchor", ktorý ",treští", "syčí, huláka a piští", predtým však Faustovi akoby mimochodom povedal: „Vetrím už nespútaných hostí.“ Akoby sa stromy lámali nielen pod náporom prírodného živlu, ale aj pod náporom pudom hnanej masy - ona je tým skutočne nebezpečným živlom. V origináli podobné intratextové väzby alebo absentujú, alebo sú inak lokalizované a majú inú kvalitu (napr. variácie slova krachen - praskat'). V preklade ich možno považovat’ za vrchol Strmeňovho prekladatel'ského majstrovstva.

\section{Záver}

Medzi slovenskými prekladmi Goetheho Fausta má fragmentárny preklad Karola Strmeňa (52 strojopisných strán uložených v Literárnom archíve Slovenskej národnej knižnice) nezastupitel’né miesto. Ortografická analýza ukázala, že pravdepodobne vznikol medzi rokmi 1945 a 1953 počas jeho exulantskej anabázy. Slobodné prostredie exilu, najmä amerického, malo i napriek prvotným existenčným t’ažkostiam na prekladovú tvorbu Karola Strmeňa zásadne blahodarný vplyv.

Koncepčne si Strmeň volí cestu kreolizácie a funkčnej ekvivalencie. V súlade s Goetheho verzológiou tvorí nápadité, nie vždy čisté rýmy. Lexikálne jednotky vyberá primerane komunikačnej situácii, v dialogických pasážach má veta prirodzený spád a civilný tón. Unikátnym javom sú intratextové väzby, ktorými Strmeň prehlbuje sémantické podložie originálu. Tu je jeho preklad kongeniálny, ak nie geniálnejší než originál.

Aj preto zahanbuje, že dosial' sa Strmeňovým prekladom z germanofónnych literatúr nevenovala náležitá pozornost'. Za svoje impozantné a sugestívne prekladatel'ské dielo in genere (ca 7000 strojopisných strán) by si nepochybne zaslúžil oficiálnu poctu a uznanie.

\section{THE SLOVAK TRANSLATION OF GOETHE'S FAUST IN THE MANUSCRIPT ESTATE OF KAROL STRMEŇ}

\section{Ján ČAKANEK}

Of the Slovak translations of Goethe's Faust, the fragmentary translation by Karol Strmeň from the late 1940s or early 1950s is completely outside the academic discourse. Until now, it has lain unnoticed in the Literary Archive of the Slovak National Library as part of the author's extensive manuscript estate transferred from the USA. The absence of its critical reflection has caused a rupture in the continuous mapping out of the Faustian translations in Slovakia and created an illusion of the unwavering status of Móric Mittelmann Dedinský's representative translation from the 1960s. The main aim of this study is to approach the personality of Karol Strmeň through the prism of extratextual factors (the socio-historical context, the subject of the translator, 
a political gesture and a political event) and to determine the extent of their influence on Strmeň's translation poetics. The latter will be analysed by employing a method of strict comparison of the structural and aesthetic dominants of the translation with Johann Wolfgang Goethe's original.

\section{LITERATÚRA}

AMAKIJO, Anami. Nad dvoma prekladmi starojaponskej poézie. In Knižná revue, 2005, roč. 6, č. $16-17$, s. 7. ISSN 1336-247X.

BANÍK, Anton, Augustín. Pravidlá slovenského pravopisu s pravopisným a gramatickým slovníkom. Turčiansky Sv. Martin : Matica slovenská, 1940. 478 s.

BORČIN, Emil a kol. Slovník slovenských nárečí, II. L - P. Bratislava : Veda, 2005. 1066 s. ISBN 978-80-224-0900-6.

CABADAJ, Peter. Literárny slovenský exil 1939 - 1990. Martin : Matica slovenská, 2002. 204 s. ISBN 80-7090-647-2.

CABADAJ, Peter. Básnická tvorba Karola Strmeňa. In Biografické štúdie 28. (Ed. Augustín Matovč́k). Martin : Slovenská národná knižnica, 2002, s. 107 - 111. ISBN 80-89023-11-8.

CZAMBEL, Samo. Rukovät’ spisovnej reči slovenskej. Turčiansky sv. Martin : Vydanie Kníhkupecko-nakladatel'ského spolku, 1902. $350 \mathrm{~s}$.

ČAKANEK, Ján - TEPLAN, Dušan. Goetheho Faust v preklade Karola Strmeňa; „Mení to mapu faustovských prekladov na Slovensku...". [Rozhovor]. In Fraktál, 2020, roč. 3, č. 4, s. 65 - 69. ISSN 2585-8912.

ČARNOGURSKÁ, Marina. Strmeňov Tu Fu po dvadsiatich ôsmich rokoch. In TU, Fu. Stokvetá rieka (výber zo staročinskych originálov). Bratislava : Petrus, 1998, s. 218 - 221. ISBN 80-967376-6-X.

ČARNOGURSKÁ, Marina. V poézii - ide o život. Kultúrny život, 2001, roč. 2, č. 49, s. 10, 5. 12. 2001. ISSN 1335-6976.

ČARNOGURSKÁ, Marina. Výnimočná hodnota Strmeňových básnických prekladov z klasickej čínštiny. In Biografické štúdie 28. (Ed. Augustín Matovčík). Martin : Slovenská národná knižnica, 2002, s. 120 - 130. ISBN 80-89023-11-8.

ECKERMANN, Johann, Peter. Rozhovory s Goethem v posledných rokoch jeho života. Bratislava : Slovenské vydavatel'stvo krásnej literatúry, 1960. $746 \mathrm{~s}$.

FRANEK, Ladislav. Štýl prekladu : vývinovo-teoretická a kritická analýza slovenských prekladov Paula Claudela. Bratislava : Veda, 1997. 160 s. ISBN 80-224-0466-7.

GAIER, Ulrich. Johann Wolfgang Goethe, Faust-Dichtungen, 2. Kommentar I. Stuttgart : Reclam, 1999. 1283 s. ISBN 3-15-030019-3.

Goethe-Wörterbuch, digitalisierte Fassung im Wörterbuchnetz des Trier Center for Digital Humanities, Version 01/21. [online]. [cit. 04. 04. 2021]. Dostupné na internete: https://www. woerterbuchnetz.de/GWB.

GOETHE, Johann, Wolfgang. Faust-Dichtungen, Bd. I. Texte. (Ed. Ulrich Gaier). Stuttgart : Reclam, 1999. 692 s. ISBN 3-15-030019-3.

KRUŽLIAK, Imrich. Živé stopy. Cambridge, Ontário : Dobrá kniha, 1975. 298 s.

MARCINČIN, Matúš. Unikátne slovenské preklady Havrana E. A. Poa a ich vplyv na pôvodnú tvorbu Karola Strmeňa. In Trends in Slavic Studies. (Eds. Enrique F. Quero Gervilla - Benamí Barros García - Tatiana R. Kopylova). Moskva : URSS, 2015, s. 237 - 247. ISBN 978-5-39600701-7.

MARCINČIN, Matúš. Slovenský Shakespeare v americkom exile. In Slovenské divadlo, 2017, roč. 65, č. 1, s. 4 -21. ISSN 0037-699X. DOI: https://doi.org/http://doi.org/10.1515/sd-2017-0001.

MARCINČIN, Matúš. Krištál na zabudnutom ostrove. (Dráma života Karola Strmeňa v súvislostiach). In Slováci v zahraničí, 35 : Zborník Krajanského múzea Matice slovenskej. (Ed. Zuzana Pavelcová). Martin : Matica slovenská, 2018, s. 8 - 42. ISSN 00810061. 
MIHALKOVIČ, Jozef. Ako nepredvídatelný letový obrat roja škorcov. In Revue svetovej literatúry, 1992, roč. 28, č. 6, s. $77-78$. ISSN 0231-6269.

MLACEK, Jozef. Osobitosti uplatňovania záporu vo frazeológii. In Slovenská reč, 2006, roč. 71, č. 2, s. $65-77$. ISSN 0037-6981.

Návštevy : antológia zo svetovej lyriky I., II. Preložil Karol Strmeň. Rím : SÚSCM, 1972. 263 s. (zv. 1); 271 s. (zv. 2).

Návštevy : antológia svetovej lyriky. Preložil Karol Strmeň. Martin : Matica slovenská, 2008. 535 s. ISBN 978-80-7090-863-1.

PAŠTEKA, Július. Predstavil nám Eminesca. In EMINESCU, Mihai. Ďaleko od teba. Bratislava : Petrus, 1999, s. 64 - 95. ISBN 80-8893-901-1.

PAŠTEKA, Július. Všetky cesty vedú domov. In STRMEŇ, Karol. Znamenie ryby. Bratislava : Petrus, 2001, s. 7 - 35. ISBN 80-9678-367-X.

PECIAR, Štefan a kol. Pravidlá slovenského pravopisu s pravopisným a gramatickým slovníkom. Bratislava : SAV, 1953. $405 \mathrm{~s}$.

PECIAR, Štefan a kol. Slovník slovenského jazyka, II. L - O. Bratislava : SAV, 1960. 648 s.

PISÁRČIKOVÁ, M. a kol. Synonymický slovník slovenčiny. Bratislava : Veda, 2004. 998 s. ISBN 80-224-0801-8.

SABOLOVÁ, Dagmar. Preklady Danteho Pekla na Slovensku a v exile. In Kotázkam teórie a dejín prekladu na Slovensku II. (Ed. Katarína Bednárová). Bratislava : Ústav svetovej literatúry SAV, 1994, s. 189 - 199. ISBN 80-967046-5-6.

SCHÖNE, Albrecht. Johann Wolfgang Goethe, Faust. Kommentare. Frankfurt - Leipzig : Insel, 2003. 1143 s. ISBN 978-3-458-34700-2.

SMIEŠKOVÁ, Elena. Malý frazeologický slovník. Bratislava : Slovenské pedagogické nakladatelstvo, 1989. $272 \mathrm{~s}$.

ŠPRINC, Mikuláš. ...za lásku sa neplatí. Martin : Matica slovenská, 2002. 276 s. ISBN 80-7090642-1.

TOMČÍK, Miloš. Kontúry prekladovej tvorby Karola Strmeňa. In Slavica Slovaca, 1991, roč. 26, č. 4, s. 267 - 279. ISSN 0037-6787.

TVRDÝ, Peter. Slovenský frazeologický slovník. Praha - Prešov : Československá grafická únia, 1933. $841 \mathrm{~s}$.

VANTUCH, Anton. Ďalší slovenský preklad Danteho Pekla. In Slovenské pohl'ady, 1966, roč. 82, č. 7, s. 134. ISSN 1335-7786.

VÁŽNY, Václav. Pravidlá slovenského pravopisu s abecedným pravopisným slovníkom. Praha : Štátne nakladatel'stvo, $1931.360 \mathrm{~s}$.

ZAMBOR, Ján. O troch slovenských prekladoch Danteho Pekla. In Romboid, 2008, roč. 43, č. 3, s. 30 - 42. ISSN 0231-6714.

ZAMBOROVÁ, Marta. Preložit báseň je ako obrátit dýku proti sebe. Rozhovor s Karolom Strmeňom. In Revue svetovej literatúry, 1992, roč. 28, č. 6, s. 71 - 75. ISSN 0231-6269.

Ján Čakanek

Katedra germanistiky

Filozofická fakulta Univerzity Konštantína Filozofa v Nitre

Štefánikova 67

94901 Nitra

e-mail: jcakanek@ukf.sk 